\title{
The Extent of the Authority of the Constitutional Court of Kuwait to Annul an Elected Parliament: The Cases of the 2012 Parliaments
}

\section{Fawaz Almutairi}

\section{Abstract}

The Kuwaiti Constitutional Court annulled two elected parliaments in the same year. The court annulled the National Assembly that was elected in February 2012 after four months of its election ${ }^{1}$, and the National Assembly that was elected in December 2012 after six months of its election $^{2}$. The two decisions had a major impact on the extent of the court's authority to nullify elected parliaments due to wrong governmental measures which have nothing to do with any parliamentary actions. The legal access to the Constitutional Court to examine the legitimacy of an elected parliament was through the exceptional authority granted to it to examine the electoral appeals. This chapter first discusses the extent of the Court's jurisdiction to examine electoral appeals and then its authority to annul an elected parliament.

The Constitutional Court has a number of competences - its inherent competence being to examine the constitutionality of laws and decrees. The control of election laws and the electoral process also fall under its jurisdiction, as is the case in several other countries of the region, for example Egypt. Here it may be considered as a normal Court where the electoral cases are appealed; whether concerning the division of constituencies or the voting mechanism. In some instances, the same court hears electoral appeals in terms of election invalidity, whether in relation to invalid legal procedures that vitiated the electoral process, or in relation to the inspection of practices during the electoral process, or in relation to arithmetic errors and erroneous announcement of results. Thus, through this appeal function and "detour" in cases, wherein the Constitutional Court examined the former Royal Decrees regarding the electoral process,

1 The election was held in February 2, 2012, and the court's decision was issued on June 20, 2012.

2 The second parliament in the year was elected in December 1, 2012, and the court's decision was issued on June 16, 2013. 
the Court has had an enormous impact on the election and on the fate of the two parliaments elected in 2012, through an authority in examining electoral appeals that is questionable.

\section{Introduction}

In this study, we will examine the role of the Constitutional Court of Kuwait and its impact on the two elected parliaments which were nullified by the Court's authority in examining the electoral dispute, and the electoral process in terms of the constitutional and legal basis, which allows it to intervene. In this context, the formation of the Court and its jurisdiction will be discussed, as well as some constitutional provisions that have influenced the electoral process. By analyzing decisions of the Constitutional Court, the effects of the constitutional rulings will be explained.

The Constitutional Court is empowered with different competences, not by the Constitution but by the election law, and is entitled to hear a variety of actions. The Constitutional Court's inherent jurisdiction is to examine the constitutionality of laws, decree-laws and regulations ${ }^{3}$. The Constitutional Court also has jurisdiction to hear parliamentary electoral appeals. In this case, the Constitutional Court examines parliamentary electoral appeals as a court of merits as it decides upon these electoral appeals, whether for reasons based on calculation or for the declaration of results. In various cases, the Constitutional Court has examined the extent of constitutionality of a law or decree-law during the examination of electoral appeals, thus, it incorporated two jurisdictions at the same time.

The Constitutional Court has played and still plays an important role in the electoral process and the checks and balances among authorities as well. It is enough to know that the Court has invalidated the election of two consecutive parliaments and restored the previous Assemblies as if the elections never held.

\section{The authority empowered to examine elections}

There is a dispute over which authority is competent to examine electoral appeals. Due to the attachment to parliament, the legislator granted the parliament the basic authority to control the electoral process. This compe-

3 Hasanin 2013: 16; Ikram 2007. 
tence of the National Assembly continued until the establishment of the Constitutional Court in 1973, up to then parliament was deciding on the validity of the election of its members. Following the enactment of the Constitutional Court Establishment Law, reviewing electoral appeals was transferred to the Constitutional Court.

\subsection{The National Assembly's competence to examine the electoral disputes}

The National Assembly was empowered with inherent competence to decide upon the validity of its members. Pursuant to Article 95, permissive jurisdiction may be granted to any judicial authority defined by law.

"The National Assembly shall determine the validity of the election of its members and the election shall not be invalidated save by majority of the members composing the Assembly. A law, however, may commit this jurisdiction to a judicial body."

When the Constitutional Court Establishment Law has been issued, the jurisdiction of the Court has been identified, including hearing of electoral appeals, which is provided in Article 1 of the $\mathrm{Law}^{4}$.

"A Constitutional Court shall be established which exclusively shall be competent to interpret constitutional texts and to adjudicate disputes concerning constitutionality of laws and decrees by laws, regulations and appeals of the election of members of the National Assembly or the validity of their membership. Constitutional Court ruling shall be binding for all courts and individuals."

The Constitutional Court Establishment Law entrusted such jurisdiction to the Constitutional Court $^{5}$ despite the fact, that the inherent jurisdiction in accordance with the Constitution, as provided in Article 95, is entrusted to the National Assembly; yet, the Rules of Procedure of the National Assembly issued on May 15, 1963 confirmed this jurisdiction.

Article 5: "Each elector may request annulment of the election that has held in his constituency and each candidate shall request that in the constituency in which he was a candidate. The request must include a statement of reasons for the appeal and be accompanied by supporting documents. The application shall be submitted to the General Secretariat of the National As-

4 Al-Sulaili 2013: 110.

5 Hasanin 2013: 61; Ikram 2007. 
sembly within fifteen days of election results announcement. If ratification cannot be done, for any reason, as provided for in the preceding paragraph, it may be made at the Secretariat of the National Assembly at the mentioned time."

Article 6: "The Speaker shall transmit requests for election invalidation to the Committee on the Elimination of Electoral Appeals and shall inform the Assembly at the following first meeting."

Article 7: "The Committee shall send a copy of the appeal to the member challenged in the validity of his membership to submit his statement of defense in writing or orally on the date fixed and may review the documents submitted. The contestant may also submit to the Committee written or oral statements explaining the reasons for his appeal."

Article 8: "The Committee may decide to summon the contestant or member challenged in the validity of his membership or witnesses and may request any Government documents for perusal and to take whatever it deems appropriate and may delegate a subcommittee or more to conduct investigations. The summoning of witnesses shall be by a letter from the Speaker of the Assembly at the request of the Committee by registered mail or the register of the Assembly's correspondence."

Election Law 35 of 1962 also required:

Article 41: "Each elector may request to invalidate the election held in his constituency, and each candidate is entitled to request that in the constituency in which he was a candidate. An application shall be submitted, with signature of elected domicile authenticated, to the General Secretariat of the National Assembly within 15 days of announcement of election results. Neither the voter nor the candidate may, in any case, challenge the request to invalidate the election that held in his constituency or in the constituency in which he was a candidate in if this appeal is grounded to settle a dispute over the electoral domicile."

Article 42: "The National Assembly if invalidated the election of one or more members and election results fully revealed, shall declare the victory of the one it believes that his $\mid$ her election is valid."

The appellant of elections results shall submit the appeal to the Constitutional Court directly or through the National Assembly as stipulated in Article 5 of Constitutional Court Establishing Law.

"Electoral appeals of the National Assembly shall be submitted directly to the Court or through the stated Council in accordance with the procedures prescribed in this regard." 
In many electoral appeals submitted to the National Assembly, the appeal has been directed to the National Assembly. In other cases, the appeal has been submitted to the Constitutional Court; the court did not reject any appeal owing to the method of submission in accordance with the prescribed provisions.

There still remains a pressing question: is the National Assembly entitled to decide upon the validity of membership of members related to the electoral appeals without referral to the Constitutional Court?

In answering this question, we assume that the National Assembly still has the competence to examine the electoral appeals for several reasons:

1. The inherent jurisdiction to examine parliament membership validity is prescribed for the National Assembly and not for the Constitutional Court; this is what is laid down by provisions of both the Rules of Procedure of the National Assembly Law and the Election Law. Giving the Constitutional Court this exceptional jurisdiction does not prevent from what we consider inherent jurisdiction proceeding.

2. The preamble of the Law 14 of 1973 Constitutional Court Establishing Law, refers neither to the Rules of Procedure of the National Assembly Law 12 of 1963 nor the Election Law, thus excluding an explicit repeal of the National Assembly's competence. As long as the Court continues to accept appeals that have primarily been submitted to the National Assembly, even the idea of an implicit repeal of the provisions of the Rules of Procedure Law may be discarded. As long as submission of appeals in accordance with the Rules of Procedure Law is applicable, the jurisdiction of the National Assembly to adjudicate the validity of its members shall also remain effective unless expressly repealed.

3. Article 39 of Election Law stipulated for the following: "The Chairman of the Committee shall hand over the committee's original boxes and envelope containing a photocopy of election minutes results to the General Secretariat of the National Assembly, to remain in office until all electoral appeals have been decided and returned to the Ministry of the Interior". Committees' original boxes and an envelope containing a photocopy of election results' minutes shall be deposited to the General Secretariat of the Nation Assembly until deciding upon all electoral appeals. This matter is still applied, which confirms that the National Assembly is the responsible authority to decide upon the validity of membership. Therefore, it does not prevent the National Assembly from continuing to examine the results of the election, particularly in the case of challenges to the calculation of votes that do not require a court decision. 
4. The Constitutional Court has a permissive jurisdiction to examine the electoral process based on the Constitutional Court Establishing Law, which decided on the power of the Court to examine the electoral appeals.

2.2. The basis of Constitutional Court's competence to examine the electoral appeals

The Constitutional Court shall have a range of powers that vary between the Constitution and the Constitutional Court Establishing Law.

In accordance with Article 173 of the Constitution, we find that the Court has the jurisdiction of:

"The law specifies the judicial body competent to deciding disputes related to the constitutionality of laws and regulations and determines its jurisdiction and procedure.

The law ensures the right of both the Government and the interested parties to challenge the constitutionality of laws and regulations before the said body. If the said body decides that a law or a regulation is unconstitutional, it is considered null and void."

Article 95 granted a permissive jurisdiction for the same judicial body as mentioned in Article 173 of the Constitution ${ }^{6}$, such jurisdiction may be given to another judicial body which the Law can limit thereof ${ }^{7}$.

Article 95 of the Constitution states:, "The National Assembly shall determine the validity of the election of its members and the election shall not be invalidated save by majority of the members composing the Assembly. A law, however, may commit this jurisdiction to a judicial body"

When the Constitutional Court Establishment Law was enacted, the jurisdiction of the Court was defined, which include hearing of electoral appeals in Article 1.

"A Constitutional Court shall be established which shall be competent to interpret constitutional texts and to adjudicate disputes concerning the constitutionality of laws and decrees by laws, regulations and appeals of the election of members of the National Assembly or the validity of their

6 Al-Tabtabai 2005: 141.

7 Alfeeli 1997. 
membership. Constitutional Court ruling shall be binding for all courts and individuals".

The said law made it a court in a full judicial nature, and entrusted it with the inherent jurisdiction prescribed by the Constitution, which is to settle disputes related to the constitutionality of laws, decree-laws, and regulations. Entrusting the Constitutional Court with permissive jurisdiction means granting it the authority to examining the appeals related to the election of the National Assembly or the validity of their membership. The Constitutional Court Establishment Law attributed a new competence to the Court which is the interpretation of constitutional provisions.

\section{Excluding Parliament from effecting the formation of the Constitutional Court}

The Constitutional Court Establishment Law has granted the government an ability to influence the selection of court members with a full exclusion of National Assembly's ability to affect. Article 2 of the Law provides for:

"The Constitutional Court shall be composed of five justices chosen by the Judicial Council by secret ballot. Two reserve members shall be elected, they shall be Kuwaiti and appointed by a decree. If any of the original or reserve members place become vacant, the Judicial Council shall, by secret ballot, the person who will replace him and shall be appointed by a decree. Court provisional and original members shall continue to function therein in addition to their original work in the Court of Cassation or the Court of Appeal."

\subsection{The method of selecting the Constitutional Court members:}

Art. 2 of the Constitutional Court Establishment Law tasked the Supreme Judicial Council members with selecting the Constitutional Court justices through secret ballot. In practice, what has been implemented is that the members of the Supreme Judicial Council select themselves, based on the interpretation that they are also to be considered a segment from which to select from - an interpretation that may be questioned. How maintain the secrecy required by the legislator on the one hand when they select themselves on the other?

The Constitutional Court is composed of five Kuwaiti justices as well as two reserve justices so as to replace the absent original member within 
normal circumstances. The court meeting shall not be valid unless all members attend; judgments are rendered by majority with the necessity to attach the minority opinion.

Worthy mentioning, since the date of its establishment until March 2015, the Constitutional Court had rejected to render judgments except unanimously. In one case, one of the justices argued that he differs in opinion with the Court's approach, however he was not allowed to disagree and judgment was sentenced unanimously, which forced him to resign from the court. In another case, a member of the Court held a separate opinion which forced the court, after the previous situation, to subject to the idea of attaching minority opinion, if any, as required by law. This was in Constitutional Case 8 of 2014, Constitutional, issued on 22 March 2015. The Constitutional Court Establishment Law also requires that the judgment shall be published in the Official Gazette within two weeks of promulgation.

\subsection{The government's power to influence the selection of the Constitutional} Court's members by decrees of appointment

Article 2 of the Constitutional Court Establishment Law requires that the Court shall be composed of five members. The members of the Supreme Judicial Council shall take the first step to select or nominate original members of the Constitutional Court and reserve members. Then the Minister of Justice shall report nominations to the Cabinet in preparation for the issuance of the decree of appointment based on the said nomination. The government thus has a direct impact on Court's formation through the use of its authority to issue decrees and its power over decrees issuance. It may thus oblige the Supreme Judicial Council to select another person in the event of reservation against a candidate.

In addition, the executive branch has the power to influence the judiciary through an annual payment of budget allocated to the judiciary and judges.

The Undersecretary of the Ministry of Justice, who is affiliated to the government apparatus is ex officio a member in the Judicial Council, and thus participates in the decisions taken by this Council. Article 16 of the Judicial Organization Law 23 of 1990 stipulates membership of Undersecretary of the Ministry of Justice in the Judicial Council. 
4. The methods of case proceeding in the electoral appeals:

The Court is empowered with different competences as stipulated by the Constitutional Court Establishment Law which are:

1. Power to examine the constitutionality of laws and decree-laws ${ }^{8}$,

2. Power to interpret the articles of the Constitution',

3. Power of hearing appeals of National Assembly members' election or the validity of their membership.

These three competences may be relevant to the electoral system or the electoral process ${ }^{10}$ : The unconstitutionality of an election or a law related to the electoral process may be challenged before the Court. Also, a request of interpretation of a constitutional text in relation to the constitutional articles dealing with the selection of the Judicial Council or membership issues thereof may be submitted to the Constitutional Court ${ }^{11}$. The case may proceed as an electoral appeal immediately after elections ${ }^{12}$.

Electoral disputes and appeals are various - there are appeals related only to the validity of a counting process ${ }^{13}$, the calculation of votes, and the announcement of results. There are appeals related to the invalidity of the stakeholder in the electoral process, whether nullification prior to the process or synchronous or after thereof ${ }^{14}$.

It has become obvious that the proceeding of electoral dispute or dispute over the constitutionality of the norms governing the electoral system to the Constitutional Court is possible through all jurisdictions and channels granted to the Court.

\section{Constitutional Court's decisions and their impact on the electoral system}

The Constitutional Court has examined numerous electoral appeals through which it dealt with the electoral process or with the electoral system. The Constitutional Court has been called upon as a body examin-

8 Abdulbaset 2002: 213.

9 Altukaim 2015: 419.

10 Muhannad 2010.

11 Almoqatie 1999: 124.

12 Alasar 1999: 133.

13 Alshakani 2005:218.

14 Al-Tabtabai 2005: 150. 
ing the constitutionality of laws with regard to some legislation related to the electoral process.

We will examine two appeals that had an impact on the electoral system:

\subsection{Constitutional challenges regarding articles of the Election Law, the division of electoral districts, or decrees related to the electoral process}

Some articles of the Election Law have been challenged at various times. Among the serious effects of decisions on constitutionality, are rulings with retroactive effect (ex post facto) as a consequence of unconstitutionality. In case a provision on the electoral process is invalidated, the inevitable consequence of this ruling is the invalidity of the electoral process as a whole, and therefore the invalidity of the elected parliament, according to this system.

The first case: The nullification of parliamentary election of February 2012.

Kuwait has a rich experience with political movements and campaigns and it had two experiences where the Constitution itself was suspended during the seventies and eighties of the last century ${ }^{15}$. It was not surprising that a political campaign was initiated demanding the departure of former Prime Minister Sheikh Nasser Al-Mohammad, in the wake of which he submitted his resignation to the Emir, especially after increasing online activism in Kuwait ${ }^{16}$; an Amiri decree was issued appointing Sheikh Jaber Al-Mubarak as his successor. Immediately Sheikh Jaber Al-Mubarak issued a decree to dissolve the National Assembly by holding a meeting with Sheikh Nasser Al-Mohammad Cabinet, based on Article 103 of the Constitution;

"Where the Prime Minister or a Minister relinquishes his post for any reason whatsoever, he shall continue to deal with urgent matters falling within his competence until the appointment of his successor."

15 From 1976-1981 and from 1986-1992. Baaklini 1982.

16 Nordenson 2017. 
The new government, as a caretaker government of urgent matters, involved ministers of the old government to issue a decree to dissolve parliament.

Decree 443 of 2011 promulgated to dissolve the National Assembly on 06/12/2011. In the decree preamble thereof, it stated to be based on Article 107 of the Constitution, mentioning that,

"if affairs returned thereof representing hindrance to the march of achievement and a threat to the supreme interests of the country, requires a return to the nation to choose their representatives to overcome the existing obstacles and achieve the national interest."

The decree showed that it has been issued based on a proposal of the Prime Minister after the approval of the Cabinet. The decree was signed by the Prime Minister Jaber Al-Mubarak.

After the dissolution of four parliaments within five years ${ }^{17}$, another new National Assembly was elected and it consisted of 50 members using the plurality allocation rule ${ }^{18}$. many of the candidates appealed to the Constitutional Court by way of electoral appeals. While some appeals were related to the non-constitutionality of the decree to dissolve parliament, its invalidity and consequent the invalidity of the decrees on which the results of the elections and the announcement of results were based on. The Constitutional Court, based on the two appeals registered No. 6 and 30 of 2012; which are appeals regarding the National Assembly election 2012, rendered judgment to invalidate the entire election process which was held on 02/02/2012 in five districts. It also invalidated the membership of those who won a seat, due to the invalidity of the prior dissolution of parliament and the invalidity of inviting voters to elect members of the National Assembly, which has been the basis of this elections. As a consequence, and most particularly, the Assembly dissolved by the power of Constitution was to be restored, as if the dissolution were null and void.

The Court pointed out that the appeal requested the nullification of elections due to the invalidity of the previous procedures - the request to dissolve the parliament filed and accepted by a cabinet, that had lost its capacity after resignation and borrowed ministers to obtain their consent to dissolution. The Court argues that this makes this procedure null and void, with no consequential legal effects arising therefrom:

17 Shalaby 2015.

18 Lust-Okar 2002. 
"Whereas this objection is valid, since Article 107 of the Constitution states that: "The Amir may dissolve the National Assembly by a decree in which the reasons for dissolution are indicated. However, dissolution of the Assembly may not be repeated for the same reasons. In the event of dissolution, elections for the new Assembly are held within a period not exceeding two months from the date of dissolution. If the elections are not beld within the said period, the dissolved Assembly is restored to its full constitutional authority and meets immediately as if the dissolution had not taken place. The Assembly then continues to function until the new Assembly is elected. Learned is that the parliament dissolution is a constitutional right prescribed to the executive authority and is deemed one of the ways to strike and maintain balance between executive and legislative powers. To request dissolution, it should be demanded by real Government (Cabinet): a government that did not lose capacity thereof, whether following a dispute with the Nation Assembly or because harmony between them is not preserved. Although the Constitution did not restrict government in the use of the right of dissolution which was not constrained by prescribed time, it is entitled to select the time and discretion of occasions, but the Constitution, owing to its gravity of dissolution, has covered dissolution by certain restrictions and guarantees. National Assembly must be dissolved by a decree stating the reasons for dissolution, which requires dissolution. The Decree is to be signed by the Amir and Prime Minister in order to become politically liable. If the Assembly is dissolved, it may not be dissolved for the same reasons again, as new elections must be beld within a period not exceeding two months from the date of dissolution...

Hence, after perusal of Sovereign Ordinance issued in 28/11/2011 to accept the resignation of the Prime Minister, included in the first Article that (Resignation of Sheikh/ Nasser Al-Mohammad Al-Abmad Al-Sabah and the Cabinet is accepted and he shall continue to discharge the urgent business thereof until the formation of new Cabinet). Following, Sovereign Ordinance dated 30/11/2011 was issued to appoint the Prime Minister, first Article provided that (Sheikh/ Jaber Mubarak Al-Hamad Al-Sabah shall be appointed as Prime Minister, assigned to nominate the new cabinet members and submit their names to issue their decree of appointment) and then issuance of Decree 443 of 2011 to dissolve the National Assembly on 06/12/2011, where promulgated pursuant to Article 107 of the Constitution ..., following the proposal of the Prime Minister, and approval of the Cabinet...

As such, the conclusion is that the dissolution is based on Article 107 of the Constitution, and at the request of a cabinet that lost its capacity after resignation thereof was accepted, after a new Prime Minister is appointed 
pursuant to Sovereign Ordinance and assigned to nominate members of the new Cabinet, it preceded Prime Minister in his current capacity, formation of this new Cabinet and issuance of decree to form thereof, and invitation of the Cabinet that lost its capacity and borrowed ministers to obtain their consent to dissolution. Such procedure is not valid from the formal point of view, violating the spirit of constitutional principles and the purpose for which its methods were defined by law. The dissolution authorized by the Constitution for the government to use, and whose nature, procedures and purpose have been defined, may not be used as a pretext to waste and violate Constitution provisions. Constitution has sanctity provisions that must be preserved and stipulations thereof must be respected.

Therefore, the dissolution is vitiated with nullity and invalidation which entails to be ignored and revoked as well as consequent invalidity of voters' invitation to elect members of the National Assembly, which based on such invalid dissolution. The will of voters is baseless as the election was created by null and void procedures where procedural restrictions in the Constitution violated as revealed.

Thus, the Appellant objection is grounded on a sound basis with no need to investigate rest of the grounds of appeal. The right of the judiciary -thento annul the election process altogether, which held on 02/02/2012 in the five districts, and invalidity of membership of those declared winners in the elections, with implications thereof, most particularly is to regain the dissolved Assembly with the force of constitutional as if the dissolution were revoked, to originally complete the remaining term..."

Our comment on this decision will be as follows:

1. The Court rejected opinion and legislation pleaded, arguing that what is raised by appellant's request is related to the invalidity of the Amiri Decree to dissolve the National Assembly as well as the Amiri Decree inviting voters to elect National Assembly's members, being irrelevant for the Court's jurisdiction to hear. Both are matters related to executive authority in relation to the legislative authority and political actions as well. The court rightly replied that the appeal was confined to the measures taken by the executive authority to dissolve the National Assembly and invite voters to the elections. The Court commented that:

"There is no doubt that the procedural restrictions imposed by the Constitution on the executive authority may not be barred or infringed or dissolved under the pretext that they are political actions, this, therefore, is inconsistent to the exercise of its restricted power in accordance with the Constitution." 
We agree with the court in such regard, procedural restrictions imposed by the Constitution are obligatory rules to follow. Otherwise, these restrictions become ineffective theories, deemed non-binding provisions within electoral appeals, and the Constitutional Court Establishment Law was futile to protect the Constitution.

The Court, in the same decision, has also applied analogy by comparing between regulatory framework, laws to decree-laws and regulations.

"It is not acceptable for constitutional system to allow judicial control over constitutionality of laws, decree-laws and regulations, in order to declare the unconstitutionality of legislation violating the Constitution ..., while some procedures, facilitating the election process issued as decisions by the executive authority, are exempted from examination and review by this court when exercising its jurisdiction to hear electoral appeals."

2. The new government presided by Jaber Al-Mubarak and the issuance of the Amiri Decree to appoint him directly ended the prior capacity of former Prime Minister. Most importantly, it ended the same capacity of the ministers that the Prime Minister drew upon in order to issue a decree to dissolve the Assembly of 2009. This entails invalidity of the decree inviting for elections, as well as of the results announced as fault-based. Since the Constitutional Court' decision had retroactive effect, the court ruled the invalidation of subsequent Assembly, which was formed through invalid decisions as stated above.

The Prime Minister has met with the Cabinet of Nasser Al-Mohammad, underlying the restriction contained in Article 128, as dissolution decrees must be issued in accordance with the provisions of this Article of the Constitution.

Article 128 "Deliberations of the Council of Ministers are secret. Resolutions are passed only when the majority of its members are present and with the approval of the majority of those present. In case of an equal division of votes, that side prevails on which the Prime Minister has voted. Unless they resign, the minority has to abide by the opinion of the majority. Resolutions of the Council of Ministers are submitted to the Amir for approval in cases where the issue of a decree is required."

Therefore, issuing decrees requires the presence and approval from a majority of the members of the Council of Ministers and may not be issued by the Prime Minister personally. The mistake committed by new government is involving the old government's constitutional capacity having been removed as soon as the new Amiri Decree was issued to appoint 
the Prime Minister. Article 129 states that, "The resignation of the Prime Minister or his removal from office involves the resignation or removal of all other Ministers."

The government in discharge of urgent matters is stipulated by Article 103 of the Constitution "Where the Prime Minister or a Minister relinquishes his post for any reason whatsoever, he shall continue to deal with urgent matters falling within his competence until the appointment of his successor."19

The capacity of this government as government in urgent matters ended once an Amiri Ordinance is issued to appoint a new Prime Minister. This is what the Cabinet of Jabir al-Mubarak has failed to abide to when he drew upon the ministers of the outgoing government to issue a decree to dissolve the 2009 National Assembly.

3. We also agree with the Constitutional Court that the constitutional legislator laid down procedural rules to issue a decree to dissolve the National Assembly, for example, in Article 107 of the Constitution. "The Amir may dissolve the National Assembly by a decree in which the reasons for dissolution are indicated. However, dissolution of the Assembly may not be repeated for the same reasons. In the event of dissolution, elections for the new Assembly are held within a period not exceeding two months from the date of dissolution. If the elections are not held within the said period, the dissolved Assembly is restored to its full constitutional authority and meets immediately as if the dissolution had not taken place. The Assembly then continues to function until the new Assembly is elected."

What would be the court's situation if the government issued a dissolution decree without reasoning, or dissolved two successive parliaments for the same reason, both of which apparently violate the restriction mentioned in this Article 107?

There is a commitment required by supreme constitutional principles and its spirit. It demands that the Constitutional Court, which is the concerned body, shall examine these decrees from a procedural point of view at least, without having access to appropriations behind issuance of such decrees. The Court has measured procedural rules in Article 107 with other rules, on the basis of which the judgment was issued. The most important of these rules was, that in order to issue a decree, a government needs to enjoy full constitutional capacity granted by the Constitution at the time of decree issuance. Through this process of measurement, the Constitutional Court found that it is entitled to invalidate the Assembly

19 Almutairi 2003: 129. 
due to the failure to observe the formal and procedural rules contained in the Constitution or even the spirit and principles of the Constitution, whereupon the Court grounded the reasoning when justifying the invalidity of the decree ordering the dissolution of parliament. It decided that the violation was not an explicit and well-defined of the Constitution, but rather a violation to the spirit and principles of the Constitution. The decision stated that, "This procedure is formally incorrect, violating the spirit and principles of the Constitution and the purpose for which its tradition was enacted."

The Court proved that the violation was not to a constitutional provi$\operatorname{sion}^{20}$, but was to the spirit of the Constitution, since it is unreasonable to allow an outgoing government to act as a caretaker government.

The second case: The Constitutional Court's decision rejecting the unconstitutionality of Law 42 of 2006

The Law on Division of Electoral Constituencies was amended by the new Law No. 42 of 2006, which divided Kuwait into five constituencies ${ }^{21}$.Every constituency elects 10 members of parliament, in which each voter has the right to cast four votes ${ }^{22}$. This law was applied in the election of February 2012 Assembly: It was the first parliament in which the government lost parliamentary majority and became politically fragile. After a lapse of less than five months, the Constitutional Court ruled, on June 20, 2012, on the requests registered in the Constitutional Court Record 6 and 30 of 2012, to invalidate the entire election process held on February 2, 2012, thus invalidating membership of those announced winners. As explained above, this was due to the invalidity of dissolution of parliament by Decree of the National Assembly 443 of 2011 as well as the invalidation of the Decree 447 of 2011 inviting voters to elect. The effect was that the dissolved Assembly of 2007 has been restored as if the dissolution had not taken place.

Therefore, the Assembly of 2009 returned, but because reform majority announced not to attend the Assembly of 2009, due to corruption issues of some members, this Assembly did not hold meetings even for once.

20 Shultziner 2012.

21 Zaccara 2013.

22 Assiri 2007. 
The government filed an appeal on 15 August 2012 before the Constitutional Court on unconstitutionality of Law No. 42 of 2006 related to the division into five constituencies in its first two $\operatorname{articles}^{23}$, the first, which divided the electoral constituencies into territorial units, and the second which gave each constituency the right to nominate 10 members, attributing four votes for each voter.

The government, in its appeal, argued on the basis of the following:

1. Determination of constituencies as stated in Article 1 of the mentioned Law and the table attached thereto was unbalanced due to inequality between the constituencies' electorate. The total number of the electorate in first constituency reached 74876 voters, while the total number of the electorate in second constituency reached 47772 voters, the third constituency reached 73065 voters, the fourth constituency 108395 voters, and fifth constituency 118461 voters. Such disparity caused a relative difference of voters in every constituency, so voters in more intensive constituencies have an over-all higher number of votes than those in smaller constituencies.

2. In spite of the disparity between voters' number within the five constituencies, each one was represented by the same number of deputies in the National Assembly regardless of the different size of each constituency, and without harmony between deputies' number and number of voters in each constituency, irrespective of how large or small.

3. The table attached to the Law has ignored to include some residential areas within some of these constituencies, for example, areas of Al-Nahda, Jaber al-Ahmad, Abu Fatira, Anijafh, Shuwaikh Industrial Area, and Shuwaikh Health District, an action which deprived resident nationals to exercise their political rights to elect their representatives in the National Assembly.

4. Article 2 of the Law specifies that the number of candidates whom each voter can vote for, may not be more than four, a matter that led to election irregularities and results that do not accurately represent Kuwaiti society.

Accordingly, the Cabinet requested to rule that Articles 1 and 2 of Law 42 of 2006 are deemed unconstitutional and to re-determine the constituencies with regard to the election of the National Assembly, arguing that they consist in a violation of the principles of justice, equality and

23 Albloshi and Alfahad 2009. 
equal opportunities, and a violation of Articles 7, 8, 29 and 108 of the Constitution.

However, the Court rejected the government's appeal and stated in its decision:

"Since the Kuwaiti Constitution did not specify the electoral constituencies and to which territory the State is divided, and did not place constraints on the determination of the number, nor on the number of deputies representing each constituency in the National Assembly, but left it to the legislator to discharge thereof in accordance with discretionary authority in this regard. In Article 81, the Constitution limited itself to state that "electoral constituencies are determined by law" namely by a legislation that addresses the determination of these constituencies, which may either be based on the population, or on geographical criteria. Such a point is supported by the discussion about the Constituent Assembly in this regard during the drafting of the Constitution in early stages, which confirms such significance.

Whereas this court does not have power to oblige the legislator to specify the number of electoral constituencies or divide thereof in a particular manner, therefore, the Law in the first Article may not determine constituencies to five constituencies which-per se-constitutes a violation to Constitution provision, in addition to the paragraph that commenced with to "determine the constituencies.." refers to the delimitation of boundaries between a constituency and another to the extent of multiplicity. This court is deprived of judicial means by which constituencies and the components of each is re-determined through entering the areas of argument that the table annexed to the law has overlooked to include into any of the constituencies referred to. The Court noted through perusal of legislative stages passed by determination of electoral constituencies that the reasons and motives referred to by the government in the appeal request are no more than the same reasons and motives referred to in the explanatory memorandums to successive laws issued in this regard, which requires to consider constituencies determination more than once, the latest is the Law No. "42" of 2006 referred to which was issued after being approved by the National Assembly.

As for the issue raised by the government in the appeal's request on the voting system in each constituency not to exceed four candidates, which is stated in Article 2 of the aforementioned Law stating that this system has been exploited in committing electoral irregularities, its application resulted in shortcomings, emergence of drawbacks and results did not truthfully and accurately reflect the nature of the Kuwaiti society and representation thereof. What the government stated in this context, as mentioned in the 
appeal's grounds, does not reveal per se a constitutional defect, and does not fit to appeal unconstitutionality for regression of court's control.

What the government has evoked, that the law determines the components of each constituency, is groundless. This discrepancy, as stated, results in relative disparity of voters, so that voters in the more densely populated constituencies have fewer votes than those in lower constituencies as per a statistical statement made in 2012. In addition to the fact that the intended equality is not absolute or computational equality, as it is not justified, in examining the constitutionality of a Law, to challenge a variable Law to render the law unconstitutional.

Therefore, the appeal is groundless; hence, it should be rejected.

Accordingly, the Court rendered judgment to reject the appeal."

The Court has set some principles that affect the electoral system:

1. The Constitution granted parliament to determine the mechanism of the constituencies ${ }^{24}$; and parliament is entitled to choose between determination on the basis of population or on a geographical basis. The selection by parliament for a certain mechanism to determine electoral constituencies is not a sufficient reason to lodge an appeal of unconstitutionality.

2. As the legislator has identified electoral constituencies on a geographical basis, the relative weight variation of the voter is not subject to challenge because equality is neither a calculation nor absolute.

3. The Constitutional Court has endeavored and blocked the way to transform Kuwait into a single electoral constituency and imposed a plurality in constituencies following the literal interpretation of Article 81 "constituencies shall be determined" when the court stated that "in addition to the paragraph that began with 'constituencies shall be determined'..." refers to the delimitation of boundaries between a constituency and another to the extent of multiplicity.

The appeal did not address the issue of constituencies' multiplicity or not, and the Constitutional Court is found to tackle such interpretation without appeal on this matter. Thus, this interpretation may be considered as unacceptable as the legislator used the word "constituencies" in plural form, which does not prevent him from personation of constituencies and vice versa. But it is clear that in the unlikely event of changing the electoral system to one constituency, fate thereof will be invalidity unless the court

24 Al-Remaidhi and Watt 2012. 
gives up this unsuccessful judicial trend ${ }^{25}$. We believe that the Court has addressed the question of the unconstitutionality of turning Kuwait into a single constituency because of proposals having been made in the 13th legislative term in 2009-2010: During this term there were three proposals to turn Kuwait into a single constituency ${ }^{26}$.

There is a political motivation of the government to challenge this Law because of its certainty that it will lose the majority in case that subsequent elections are held in accordance with the same rules of five constituencies and 10 seats and four votes for every voter. So, the government turned to the Court as it may invalidate the system and thus allows government to avoid the political embarrassment to choose another system.

The Court, on September 25, rejected government appeal of Law 42 of 2006. On October 7, Decree No. 241 of 2012 was issued to dissolve the 2009 Assembly as a result of members' majority refusal to attend, and hearings, therefore, could not be held. On 2 October, Decree Law 20 of 2012 was issued amending Law 42 of 2006 on the re-determination of electoral constituencies, including a replacement of the provision that Article 2 of the law referred to, which stipulated that "each constituency shall elect 10 members of the Assembly and each voter has the right to cast a vote for one candidate in constituency wherein he registered, voting for more than this number shall be deemed null and void".

This decree caused a severe political crisis in Kuwait which had started by the elections' boycott that was supported by Single Vote System, and a large nonviolent movement had been initiated and called karamt watan, "The nation's dignity" 27 . Such crisis is still arising up to the present time.

The government also issued Decree Law No. 21 of 2012 to establish the Supreme National Electoral Commission to control the electoral process in order to grant the judiciary more control over the electoral process and what is related to it.

The third case: The nullification of parliamentary elections of December 2012

Following the issuance of several decrees in the period between the dissolution of the 2009 Assembly which returned by virtue of Constitutional Court judgment and between the election of next Assembly, a decree was

25 Almutairi 2015: 11.

26 Alawadhi 2010.

27 Albloshi and Herb 2018. 
issued, the Decree 20 of 2012, to transfer voting mechanism of four votes per person to one vote ${ }^{28}$, while maintaining the division of electoral constituencies to become five constituencies wherein 10 members are elected in each. Also Decree 21 of 2012 was issued to establish the Supreme National Elections Commission in order to impose more control and judicial supervision over elections.

The government was seeking to impose the single vote as a tactic to break the parliamentary majority; a majority which was formed under the four votes system in the first judicially rescinds Assembly which has been elected in February 2012. It was a step that resulted in a state of fierce anger in Kuwait at the level of political movements and various societal forces and entailed a wide campaign to boycott the parliamentary elections. The first elections under a single vote system were held on December 1, 2012. The participation rate reached 39\%, which is a low figure compared to the previous elections, which were up to nearly $70 \%$, rather, some believe that the declared figure of $39 \%$ is not real, and the rate was lower, but the government pressed to give the false impression that the participation was reasonable.

More than fifty election appeals were submitted after the elections were held on December 1, 2012 $2^{29}$, as they represent the closest and expedite means to have access to the Constitutional Court. Some of these appeals were purely electoral, related to counting the votes and membership declaration, others were appeals of unconstitutionality of decrees which amended the electoral system, among them the Single Vote Decree and the Decree to establish Supreme National Elections Commission.

The former parliament's opposition anticipated the Constitutional Court's decision on this decree specifically. Opposition was not concerned about invalidity of neither the existing Assembly nor the accompanying decrees but was only concerned with the invalidity of Decree No. 20 of 2012, the Single Vote Decree. Speaking of opposition in Kuwait, it needs to be mentioned that the opposition was not considered a minority ${ }^{30}$, but was constituting the majority at this time, as governments in our countries (the Gulf region) are constituted from sons of royal family without taking into account the parliamentary blocs and partisan organizations ${ }^{31}$.

28 Tavana 2018.

29 Katzman 2012.

30 Freer 2018.

31 Coates Ulrichsen 2014. 
The Constitutional Court's decisions on these decrees have had a dramatic impact on the elections in Kuwait. Before the judgment was issued, most of the political forces were boycotting the elections because they were convinced of the invalidity of the decree of Single Vote and the necessity to dispose thereof.

Still, the Court's decision has confirmed the Single Vote Decree. In return, the first Parliament based on a Single Vote was rescinded under the pretext that Decree 21 of 2012, on the establishment of the Supreme National Elections Commission, did not meet the requirements of "necessity" as an objective condition. The decision resulted that boycott continued partially with some independent political forces deciding to participate in the elections held in 2013 due to the court deciding upon constitutionality of this decree. Until now, the political situation in Kuwait is still in a case of disturbance owing to this decision.

The decision has diversely dealt with several issues and the impact on the electoral process as well. On the one hand, the judgment has replied to some appeals, on the other responded to the Opinion and Legislation Department which is a body entrusted with the defense of the government and the defense of decrees issued by the government accordingly, which is as follows:

The Court explained the appeal filed by the appellant on non-constitutionality of Decrees 20 of 2012 and Decrees 21 of 2012 on the grounds that, in Article 71, the Constitution granted the government the right to issue decrees with the force of law under the following conditions:

1. Absence of the Assembly,

2. Existence of a state of necessity that justifies the use of this exception,

3. The decrees do not violate the Constitution and financial estimates contained in the general budget,

The appellant held that these decrees lacked an essential condition for issuance which is the state of necessity ${ }^{32}$.

But the court responded to this plead in respect of Decree 20 of 2012, which replaced the voting system from four votes to single vote as follows:

1. The legislations are, principally, issued to fulfill the needs of the nation through legislature, but the constitutional legislator has given the government this extraordinary authority in urgent cases, as required by emergency events. 
2. The Court indicated that the state of necessity does not only mean occurrence of a new emergency, but ongoing events can gain the same description "measures that cannot be delayed " as stated in Article 71 of the Constitution.

3. These decrees shall be inevitably presented to the National Assembly to definitively acquire the legal capacity, which leads to control by parliament. In addition, judicial control also expands over these decrees.

4. The government has been challenged before the Constitutional Court with regard to the Law on Division of Electoral Constituencies and the voting mechanism with four votes, which showed the flaws of this system and how it denied a balanced representation of all segments of society. Yet, after the Court rejected this appeal, the government has tried to invite the Assembly of 2009 to attend the sessions to modify the system, but as members refused to attend for political reasons, the government had no choice but to dissolve the parliament and thus issuing the appealed decree to confront the passivity of previous electoral system ${ }^{33}$.

5. The Court stated that Single Vote System is applicable in democratic countries giving minorities the opportunities to be represented in the parliament.

6. The Electoral Affairs do not determine a right, so the applicable system can be replaced by another according to the public interest.

7. To say that the government may pay attention to its special interests in the electoral system, this is not acceptable as MPs have their supposed special interest in this regard because their fate is to run as candidates in the future.

Hence, the Constitutional Court rejected the appeals filed against Decree Law 20 of 2012, which replaced the Four Votes System with Single Vote System.

The government, preserved the Single Vote System, but annulled the first National Assembly (which was elected under this system), on the basis that Decree 21 of 2012 on the Supreme National Elections Commission was null and void for not meeting the requirement of necessity in accordance with Article 71 of the Constitution.

The Court stated in the decision that "it cannot be imagined that (State's Supreme interest) called for the issuance as stated in the explanatory memorandum of the decree, as State's Supreme interest is the greater and of

33 Alshayji 2009. 
highest degree and not to be purely reduced to establish a committee in order to achieve greater integrity and transparency."

The Court continued ..."The result is that this decree, actually, represents a blatant violation to Article 71 as well as the purposes for which this article stipulated. For words of the constitution to prevail and preserve the provisions and entity thereof to abide by its provisions, the judiciary has rendered the right judgment to declare the above-mentioned Decree-law 21 unconstitutional".

The Court's decision in this regard required to eliminate the decree since its inception, to disempower its enforceability and to remove its resulting legal effects. The election process took place on the first of December 2012, and was held in accordance with the procedures established under this decree-as from nomination procedures until the end of the declaration of results. It has been vitiated by invalidity of the decree-law declared unconstitutional Law-decree, which was contested on this assumption. The will of the voters, in this case, was in lack of a valid legal basis, and thus becomes incumbent upon the judiciary to invalidate the entire process of election in five constituencies, and to invalidate the membership of those declared winners along with the consequent effects; most particularly is, to have elections repeated, and to consider Decree-Law 21 of 2012 as not having been issued.

Hence, the Court stated the consequences of the invalidity of DecreeLaw 21 of 2012:

1. No state of necessity to establish the Supreme National Elections Commission and that the decree of necessity does not support the government to establish a committee.

2. Invalidity of this decree entails invalidity of the parliament, which was elected based on the provisions of this decree.

We find that the Court did not content itself with the invalidity of the abstract provisions but accessed to invalidate the election of the whole authority, as the second National Assembly, parliament, elected in the same year, consecutively rescinded.

\subsection{The consequences of Constitutional Court's decision declared} unconstitutionality of decrees related to the electoral process

The Constitution did not desire a court in the technical sense to hear constitutional issues to exist, rather called it "judicial body". Article 183 stated 
that, "The court shall decide to rule", so the court renders a decision not a rule. When the legislator desired to organize this body, he turned it into a complete Court and made it issue provisions in case of constitutional actions and issue decisions in the event of requests for interpretations of constitutional provisions.

The legislator decided that the decisions rendered by this court shall be legally binding and stamped with the executive formula in accordance with Article 23 of the Constitutional Court Establishing Law. The judgment is binding to all courts. The constitutional judgment prevails upon all parties, not only the action parties.

\section{Appeals Examination Committee and its authority on constitutional challenges}

The Constitution equalized between government and concerned parties to resort to the Constitutional Court. The Constitutional Court Establishing Law, since issued in 1973 until 2015, was depriving persons of direct appeal before the Constitutional Court, while giving the government and parliament the right to recourse directly to the Constitutional Court. It also gave ordinary courts the authority of direct referral to the Constitutional Court based on a plead the ordinary court submitted motu proprio. As for individuals, their only means to reach the Constitutional Court was to have a case pending before ordinary courts and then lodge an appeal of unconstitutionality of a provision to be applied in case. If the court rejected, the only choice is to challenge court's decision before a committee called the Commission of Appeals Examination. This committee is composed of three members of the Constitutional Court. It examines the appeal and in case of acceptance thereof, the constitutional action shall be registered before Constitutional Court. In case of rejection, its rejection shall be final and no way to challenge it. Then this person will have way to resort to the Constitutional Court.

The committee examines the extent of seriousness of the constitutional appeal but does not examine the subject of the appeal. The reality proves that the court goes beyond its powers and addresses the subject, moreover, it sometimes, has developed new theories opposing the constitutional provisions.

This Committee is created by the Constitutional Court Establishing Law as a means of filtering appeals in order to avoid that the Constitutional Court is overwhelmed by an unnecessary flood of appeals. Nevertheless, whom who knows such justification will be surprised that the Constitu- 
tional Court Establishing Law did not ensure the complete availability of court members to their function in the Constitutional Court. The provision was disappointingly making members of the Constitutional Court continue to work in the ordinary courts, assigned to carry out the duty of members of the Constitutional Court as well as their original work. The creation of the Appeals Examination Committee to ease the proceedings before the Court is inconsistent with the notion of judges' part-time work, but rather underlines the need to assume the office of the Constitutional Court only.

Appeals by individuals are divided into two stages; the first stage was the only one existing prior to the issuance of Law 109 of 2015, a law related to the right of persons to directly lodge a complaint in front of the Constitutional Court. Until then, persons did not have the right to directly lodge an appeal of unconstitutionality, but they were entitled to invoke unconstitutionality through a plea of unconstitutionality during a court's hearing of a case wherein she or he is a party.

\subsection{The period before amending the Constitutional Court's establishment law}

At this stage, individuals had no right to directly appeal before the Constitutional Court, despite the fact that individual persons are mentioned as persons concerned in Article 173 of the Constitution. It was a decried trend to deny what is mentioned in the Article namely; to deny to individual persons to have a direct appeal, while allowing the National Assembly to have a direct appeal despite the lack of constitutional provisions which states this right to the Assembly.

The right of individuals to lodge an appeal of unconstitutionality was made by plea through court's hearing of dispute as follows:

The person must have a case or dispute before a Court of Merits such as administrative or civil or criminal judiciary.

When hearing the dispute, the person shall be pleading to lodge an appeal of unconstitutionality of the provision to be applied to the dispute.

The court of merits hears the dispute and shall consider the seriousness of the appeal as follows:

- If the plea is serious, the matter will be referred directly to the Constitutional Court to set a session for hearing and examining the constitutionality of the contested law. The Constitutional Court shall decide the constitutionality/unconstitutionality of the law. 
- If the court holds that the plea is trivial, the plea shall not be transmitted to the Constitutional Court and shall be rejected, but the rejection owing to lack of seriousness by a court of merits is not final. The appellant of unconstitutionality may challenge the decision on lack of seriousness before a committee called Appeals Examination Committee which is a judicial committee emanating from the Constitutional Court as an associate court organ to facilitate the subsequent issues of the courts of merits. This committee is composed of three members of the Constitutional Court; its task is to examine the validity of a court of merit's ruling only concerning seriousness of plea, and shall not decide upon constitutional proceedings.

- If the Appeals Examination Committee decided the plea's lack of seriousness, it shall approve the judgment rendered by the court of merits, and the judgment of the Committee's decision shall be final and not appealable.

\subsection{The period after amending the Constitutional Court's Establishment Law}

Due to the widespread criticism with regard to deprivation of individual persons from direct appeal before the Constitutional Court, the Parliament has issued Law 109 of 2014, which opened a direct route for individuals to resort to the Constitutional Court as an amendment to the previous law. The Law which consists of one Article states that:

"Any natural or legal person may appeal an original action before the Constitutional Court against any law or decree-law or regulations if he has serious suspicions that it violates the provisions of the Constitution, and had a personal a direct interest to challenge thereof. The notice of appeal shall be signed by three lawyers admissible before the Constitutional Court. The applicant shall deposit, at the time of submission of the appeal notice, a five-thousand-Dinar as a surety, clerk administration shall not accept the appeal sheet if it is not attached by proof of bail. Deposit of one bail in case of multiple applicants is enough if they lodged their notice of appeal as one statement, even for different reasons for appeal. The appeal will be presented to an in-camera hearing. If the court holds that the appeal falls outside the scope of court's jurisdiction or not acceptable formally, it shall decide to reject thereof and confiscate the bail decision by unchallengeable decision through brief reasons proved in the minutes of the meeting. If the court holds otherwise, another session to hear the appeal shall be specified." 
Any person, whether a natural or legal body, including companies and associations, shall be entitled to directly lodge an appeal of unconstitutionality of a law or regulation before the Constitutional Court, the law stipulating certain conditions, namely:

1. To pay a bail of 5,000 Kuwaiti Dinars in every notice of appeal no matter how many applicants are there.

2. The notice of appeal shall be signed by three lawyers admissible before the Constitutional Court.

3. The plea shall be serious: the appellant shall be intending to cancel the contested provision, without aiming to prolong the dispute.

4. Existence of interest to lodge an appeal of unconstitutionality of the law or regulations. This is considered as given when the application of the contested legislative provision affects the rights guaranteed by the Constitution in a manner that causes a direct damage to the appellant. Interest must be legal, personal, direct, and existing interest.

5. In this case, appeal shall not be presented directly before the Constitutional Court, but shall be brought before an in-chamber hearing of the Constitutional Court, which means part of the Court's members. If the chamber of the Court holds that: a) it falls outside the scope of court's jurisdiction, b) or is formally inadmissible, c) or the appeal is not serious, it decides not to accept the appeal and confiscate the bail amount by a decision that cannot be appealed.

6. If the chamber of the Court accepted the appeal, the in-chamber hearing Court shall call for the case to be heard before the full Constitutional Court.

\section{Conclusion}

After examining the constitutional decisions, it became clear how the court had a significant impact by examining electoral appeals, through which the court annulled two elected successive parliaments in 2012. The Constitutional Court has the tools to affect the electoral process, either through reviewing the legal dispositions related to electoral process, by determining their constitutionality, or through the examination of the electoral disputes and electoral process, whether in phases prior or simultaneous or subsequent thereof. The constitutional decisions have had direct political implications to the extent of disrupting the country's general political scene, which is witnessed by Kuwait since 2012 until now. Constitutional Court is the last resort on constitutional proceedings and electoral 
appeals. Some electoral appeals have been accompanied by significant effects such as the invalidation of two National Assemblies due to the examination of electoral appeals.

The court is facing huge political challenges because of its exceptional authority in examining the electoral appeals which was inherently rendered to the parliament itself. We believe that there will be amendments to the court's law, either by withdrawal of such an authority or by participation of the National Assembly in the process of the court's formation and selection either in the nomination process or in the confirmation process. In addition, transformation may occur to the by entering non-judiciary-based elements in the Court's formation process as the Constitution requires.

\section{References}

Alasar, Ysri. 1999. The Role of Practical Considerations in Constitutional Judgments. 1999.

Alawadhi, Abdullah. 2010. Electoral Districts and Public Costs. Master's Thesis, Kuwait University, Faculty of Law. December.

Albloshi, Hamad, and Faisal Alfahad. 2009. "The Orange Movement of Kuwait: Civic Pressure Transforms a Political System.” In: Civilian Jihad. New York: Palgrave Macmillan: 219-232.

Albloshi, Hamad H., and Michael Herb. 2008. "Karamet Watan: An Unsuccessful Nonviolent Movement.” The Middle East Journal 72.3: 408-430.

Abdulbaset, Mohamed Fouad. 2002. The Jurisdiction of the Supreme Constitutional Court. Alexandria: The Knowledge Facility.

Alfeeli, Mohammed. 1997. "Trends of the Kuwaiti Judiciary in the Appeals Concerning the Elections of the National Assembly." Journal of Law 3: 21.

Almoqatie, Muhammad. 1999. A Study in the Trends of the Kuwaiti Constitutional Judiciary. Kuwait: Kuwait University Press.

Almutairi, Anfal. 2015. Constituencies in the Kuwaiti Constitution. Master thesis, Kuwait University Faculty of Law.

Almutairi, Mona. 2003. The Prime Minister in the Kuwaiti Constitutional System, Thesis, Kuwait University, Faculty of Law.

Al-Remaidhi, Abdullah, and Bob Watt. 2012. "Electoral constituencies and political parties in Kuwait: an assessment.” Election Law Journal 11.4: 518-528.

Alshayji, Abdullah K. 2009. "The 2009 Kuwaiti parliamentary election: the challenges and the future of the Kuwaiti democratic paradigm." Contemporary Arab Affairs 2.4: 602-617.

Alshukani, Abdellah Shehata. 2005. The Principle of Judicial Supervision on Public Voting. University Thought House. 
Al-Suliali, Abdulaziz. 2013. The Legal System of Election Control: Comparative Study among the Kuwaiti System, the Egyptian System and the French System. Master Thesis, Mansoura University, Faculty of Law.

Al-Tabtabai, Adel. 2005. Kuwait's Constitutional Court, formation, jurisdictions, and procedures thereof. Scientific Council for Publications.

Altukaim, Faten. 2015. Parliamentary oversight of the necessity.

Assiri, Abdul Reda. 2007. "The 2006 parliamentary election in Kuwait: A new age in political participation.” Digest of Middle East Studies 16.2: 22-44.

Baaklini, Abdo I. 1982. "Legislatures in the Gulf area: The experience of Kuwait, 1961-1976." International Journal of Middle East Studies 14.3: 359-379.

Coates Ulrichsen, Kristian. 2014. "Politics and Opposition in Kuwait: Continuity and Change." Journal of Arabian Studies 4.2: 214-230.

Freer, Courtney. 2018. "Exclusion-moderation in the Gulf Context: Tracing the Development of Pragmatic Islamism in Kuwait." Middle Eastern Studies 54.1: $1-21$.

Hassanein, Ibrahim Mohamed, and Akram Allah Ibrahim Mohamed. 2013. Judicial Control over the Constitutionality of Laws in the Egyptian Constitutional System. Alexandria: Knowledge Facility.

Katzman, Kenneth. 2012. "Kuwait: Security, Reform, and U.S. Policy.” Library of Congress, Washington D.C., Congressional Research Service.

Lust-Okar, Ellen, and Amaney Ahmad Jamal. 2002. "Rulers and Rules: Reassessing the Influence of Regime Type on Electoral Law Formation." Comparative Political Studies 35.3: 337-366.

Mohamed, Ikram Abdelhakim. 2007. Electoral Appeals in the Legislative Elections. The Modern University Office.

Muhannad, Hassan Mohamed. 2010. Parliamentary Elections Disputes. Legal Books House.

Nordenson, Jon. 2017. "The Language of Online Activism: A Case from Kuwait." In: The Politics of Written Language in the Arab World. Brill: 266-289.

Sari, George Shafiq. 1995. Jurisdiction of the Supreme Court of Interpretation. Dar al-Nahda al-Arabiya.

Shaker, Radhi. 2005. Jurisdiction of the Constitutional Judge in Interpretation.

Shalaby, Marwa. 2015. Women's Political Representation in Kuwait: An Untold Story.

Shultziner, Doron, and Mary Ann Tétreault. 2012. "Representation and democratic progress in Kuwait.” Representation 48.3: 281-293.

Tavana, Daniel L., et alii 2018. Pluralism and Inclusion in Post-2011 Kuwait.

Zaccara, Luciano. 2013. "Comparing Elections in Gulf Cooperation Council Countries after the Arab Spring: The United Arab Emirates, Oman, and Kuwait.” Journal of Arabian Studies 3.1: 80-101. 